\title{
DIRTY AIR FILTER SYSTEM USING BOXED EQUALIZER MQ-8 AND MQ-9 WHEELED ROBOT
}

\author{
Anggara Trisna Nugraha
}

\begin{abstract}
Air is the layer of gas that envelopes the Earth. Clean air is air free of pollutants or substances that can many plants. Thus, the result of carbon monoxide emissions that have been processed will produce oxygen gas because the steel plate on the Box Analizer serves as a carbon element binder. This applied model does not change the shape of the vehicle so that the vehicle is able to process the carbon monoxide gas outside the system. In this test is used smoke from paper burning to provide action on the sensor. The amount of smoke which is the form of output already in the form of ppm (part per million) can be known by using the display on the serial monitor and with calibration using a gas analyzer. Gas analyzers are in the lowest range of $120 \mathrm{ppm}$ detecting sensors of $116 \mathrm{ppm}$ with a percent error of $17 \%$.
\end{abstract}

Index Terms-Clean air, Gas analyzer, MQ-8 AND MQ-9

\section{INTRODUCTION}

$A$ ir is the layer of gas that envelopes the Earth. The air is intangible, colorless, odorless, and can not be seen. Clean air is air free of pollutants or substances that can poison the body and are commonly found in areas with many plants. The air content (1) under normal circumstances consists of oxygen $(20.94 \%)$, carbon dioxide $(0.30 \%)$, nitrogen $(78 \%)$, argon $(0.93 \%)$, other gas gases $(0.02 \%)$.

In (2) it is explained that the corona can decompose cigarette smoke from $746 \mathrm{ppm}$ to $0 \mathrm{ppm}$ in 23 seconds. In the journal (3) the cigarette decompresser is only present in one place. But in reality cigarette smoke can not be controlled to lead to which side, so it takes a lot of decomposers. To reduce expenditure in the use of too many decomposers, with use refers to the journal and added with a robot behavior based control method then the author took the title "Dirty Air Filter System Using Boxed Equalizer Mq-8 and Mq-9 On Wheeled robot"..

\section{ANALYSIS}

1. Block Diagram

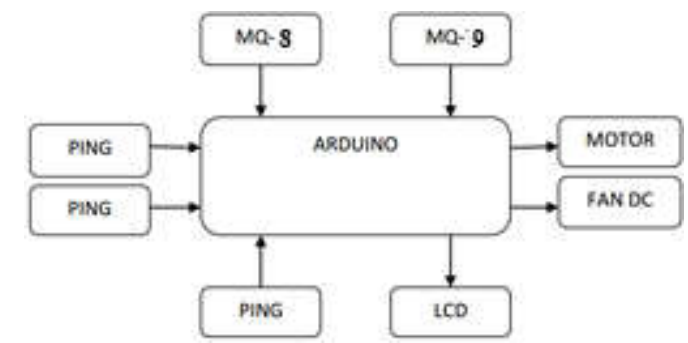

Fig 1. Block diagram of search robot and cigarette smoke decompressor [1]

From the block diagram above can be seen that there are three sensors that are as input. The PING sensor on the robot is responsible for measuring the distance between the robot and the wall in the room. In the application of PING sensors that control the movement of robots. The PING sensor detects the distance it will then be processed by the Arduino. If the result of the PING sensor is too close to the wall then Arduino will condition the situation with the output on the motor to avoid collision with the wall.

Then as has been known sensors MQ-8 AND MQ-9 as a detector of carbon monoxide gas $\mathrm{CO}$. This gas sensor will calculate the gas as it enters and exits the Box Analizer. The result of the gas state at entry and exit will be compared by Arduino as microcontroller and displayed on the LCD. Fan is influenced by input from existing gas sensors. Fan takes the resources from the battery in order to be able to rotate with the stable according to the conduits connected to the Arduino Uno R3 digital pin to be able to suck the air into Box Analizer when needed

\section{Algorithm}

In the study there are algorithms that will be used as the basis of research. In this smoke decay robot using behavior based control method. In behavior based control there are several flow diagrams according to the behavior on the robot. In this research there are two flow diagrams, namely exploration and decomposition of smoke 


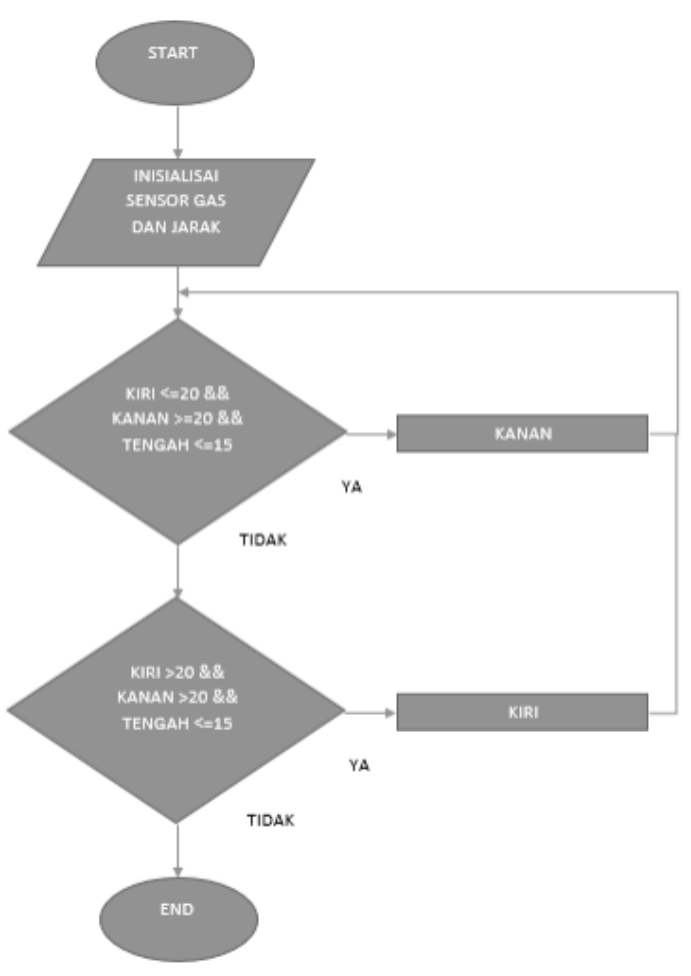

Fig 2. Robot navigation flow diagram

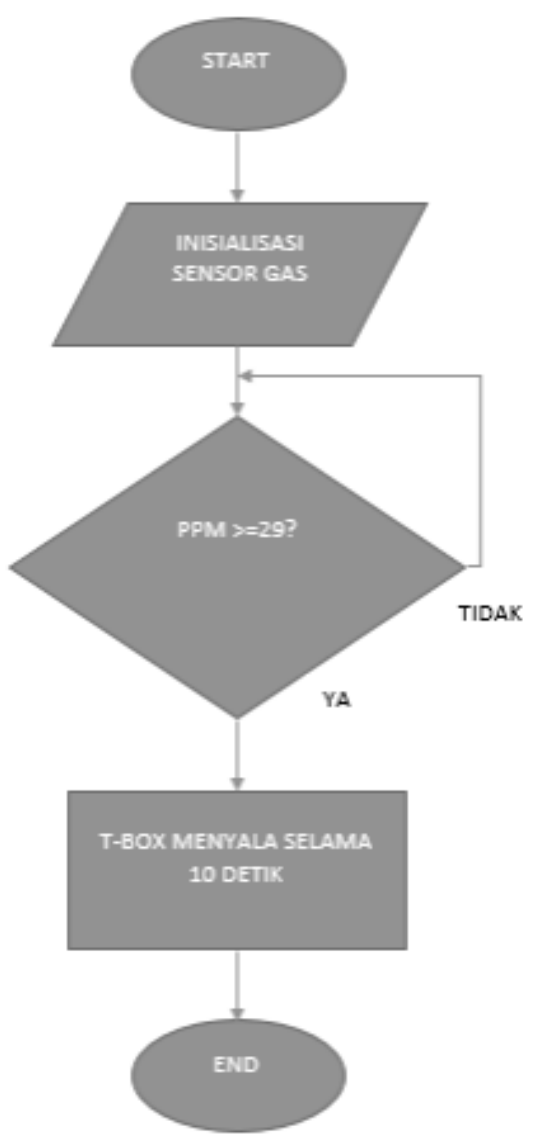

Fig 3 Flowchart of smoke flow

\section{Exploration}

From the above flow diagram can be seen that when the robot is turned on, the sensor will initialize. After initializing the robot then do the robot arena mapping. The PING sensor will detect which direction the robot should run. Due to the robot using the wall following the PING sensor on the left becomes the benchmark. If the left sensor is less than $20 \mathrm{~cm}$ away then the robot will move to the right away from the wall. If the left sensor is more than $20 \mathrm{~cm}$ away then the robot will move to the left approaching the wall. This continues until the robot finds smoke.

When the robot is in the area of cigarette smoke, the smoke sensor will soon detect. When the smoke sensor detects cigarette smoke, the BOX ANALIZER will light up to suck up the smoke and will be neutralized for 10 seconds. After 10 seconds the robot passes back on the exploration flowchart. If there is still smoke around the robot, the robot will again suck the smoke for 10 seconds. This will happen continuously until the robot is turned off..

\section{RESULT AND DISCUSSION}

Discussion of the results of the testing of the water purification device is composed of several discussions of test results such as sensor testing, Arduino Uno R3 testing, relay testing, power supply testing, sensors and testing system as a whole

a. PING Distance Sensor Testing

The distance sensor on the robot is used to be able to detect obstacles around the robot so that the robot does not hit something. PING has a sensor with two transmitters that function as trigger and echo. In the robot there are 3 (three) pieces of sensor to support robot maneuvers.

In testing distance sensor used ruler as a distance parameter in theory of $5 \mathrm{~cm}, 10 \mathrm{~cm}$, and $15 \mathrm{~cm}$. Results from sensor readings are displayed on monitor series in Arduino software

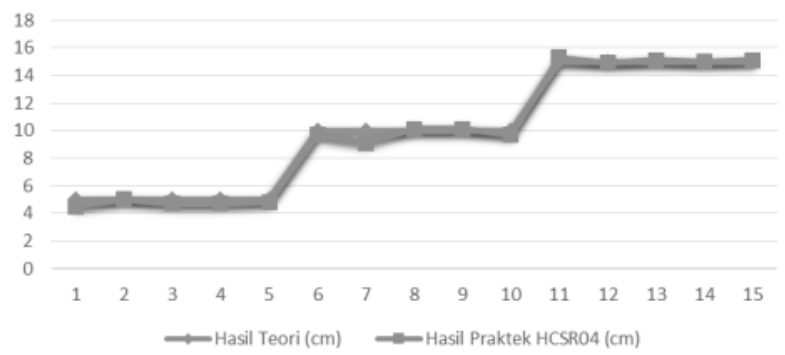

Fig 3. Graph comparison of distance measurement on the right PING sensor

The comparison table of distances read by the PING sensor obtained error percent $(\%)$, using the percent error formula with the formula in 4.1 as follows: 


$$
\text { Error } \%=\left|\frac{H T-H P}{H T}\right| * 100 \%
$$

HT $=$ Theoretical Results (Thermometer Temperature)

$\mathrm{HP}=$ Measurement Results (Temperature sensor)

\section{b. Sensor MQ-8 and MQ-9}

In this smoke sensor testing is used serial monitor reading on arduino IDE software. In this test is used smoke from paper burning to provide action on the sensor. The amount of smoke which is the form of output already in the form of ppm (part per million) can be known by using the display on the serial monitor and with calibration using a gas analyzer. The smoke sensors used are MQ-8 AND MQ-9. With the provision of a source of smoke the plastic combustion is at a distance of $5 \mathrm{~cm}$ from the MQ- 8 and MQ-9 sensors

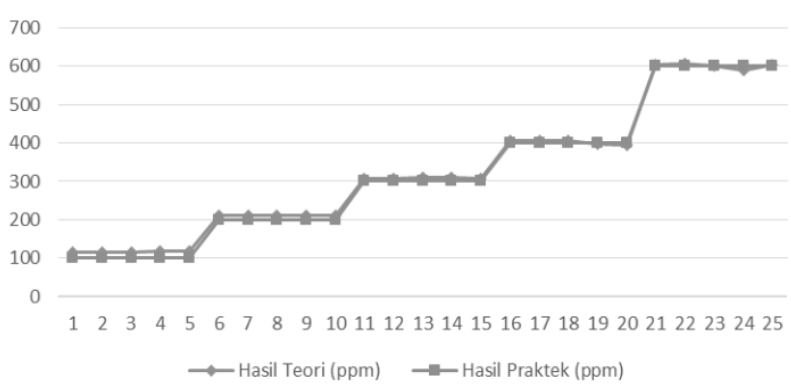

Fig 4. Graphical testing of MQ-8 AND MQ-9

Figure 4 shows that when the gas analyzer is in the lowest range of $100 \mathrm{ppm}$ detecting sensor is $116 \mathrm{ppm}$ with a percent error of $16 \%$. And when the gas analyzer is in the highest range of $600 \mathrm{ppm}$, the sensor detects $603 \mathrm{ppm}$ with error of $0.5 \%$.

\section{c. Decomposition of Smoke}

Under the smoke decomposition conditions it should be understood that under these conditions the MQ-8 AND MQ-9 gas sensors have detected the presence of cigarette smoke. after cigarette smoke is detected then the prototype will stop and then Box Analizer starts to work. The Box Analizer starts working characterized by a DC fan starting to smoke smoke into the Box Analizer and the electric corona starts filtering out the carbon content.

The smoke decomposition process occurs when the MQ8 AND MQ-9 gas sensor has detected CO gas of $29 \mathrm{ppm}$. When the CO is around the prototype of $29 \mathrm{ppm}$ or more then the prototype will stop. Once stopped then the Box Analizer will light up to suck smoke around the prototype from the front thrown backwards. The lit corona will filter the carbon in $\mathrm{CO}$ and let $\mathrm{O}$ out. Oxygen (O) is not able to stand alone as the gas combines with other oxygen so that the output of gas $\mathrm{O} 2$ (Oxygen) and $\mathrm{O} 3$ gas (Ozone). This causes the process to be called ionization
Table 1. Decomposition results in smoke decomposition

\begin{tabular}{|c|c|c|c|c|}
\hline $\begin{array}{c}\text { MQ-8 } \\
\text { DAN MQ- } \\
9 \\
(\mathrm{ppm})\end{array}$ & \multicolumn{2}{|c|}{ Box Analizer } & \multicolumn{2}{c|}{ Tegangan (V) } \\
\cline { 2 - 5 } & Korona & Fan DC & Korona & Fan DC \\
\hline 31 & On & On & 3,8 & 14,2 \\
\hline 32 & On & On & 3,8 & 14,2 \\
\hline 32 & On & On & 3,8 & 14,2 \\
\hline 32 & On & On & 3,8 & 14,2 \\
\hline 31 & On & On & 3,8 & 14,2 \\
\hline 30 & On & On & 3,8 & 14,2 \\
\hline
\end{tabular}

d. Overall System Testing

This test is performed to find out the smoke sensor results when it detects smoke. Smoke given in the form of smoke from the combustion of tissues. This test is done by burning the material in a container box with a fan on one side. Then when the prototype enters a room then the smoke will be directed to the room. The prototype will detect the presence of smoke and will break down the smoke.

Table 2. The overall results of smoke sensor testing MQ-8 AND MQ-9

\begin{tabular}{|c|c|c|c|c|}
\hline $\begin{array}{c}\text { MQ-8 } \\
\text { AND } \\
\text { MQ-9 } \\
\text { front } \\
\text { (ppm) }\end{array}$ & $\begin{array}{c}\text { MQ-8 } \\
\text { AND } \\
\text { behind } \\
\text { (ppm) }\end{array}$ & $\begin{array}{c}\text { Front and } \\
\text { back } \\
\text { differences }\end{array}$ & $\begin{array}{c}\% \\
\text { parsing }\end{array}$ & $\begin{array}{c}\text { Time } \\
\text { needed }\end{array}$ \\
\hline 31 & 26 & 6 & $10.34 \%$ & 3.20 \\
\hline 31 & 26 & 3 & $18.75 \%$ & 3.21 \\
\hline 30 & 25 & 3 & $9.37 \%$ & 3.21 \\
\hline 32 & 26 & 6 & $18.75 \%$ & 3.20 \\
\hline 31 & 25 & 3 & $9.37 \%$ & 3.20 \\
\hline 30 & 27 & 4 & $12.90 \%$ & 3.21 \\
\hline \multicolumn{2}{|r|}{ Rata-rata } & 4.2 & $12.495 \%$ & 3.20 \\
\hline
\end{tabular}

It can be seen in Table 4.8 that the smoke decay results. In the first experiment there was a reduction of 4 ppm, which means $12.9 \%$ of the initial sensor readings of $31 \mathrm{ppm}$. And the prototype clocked 3 minutes 20 seconds for one round with 1 minute 30 seconds when it reached the smoke. Then a second experiment occurred a reduction of $3 \mathrm{ppm}$ which means $10.34 \%$ of the initial sensor readings of $29 \mathrm{ppm}$. And the prototype clocked 3 minutes 21 seconds for one round with 1 minute 29 seconds when it reached the smoke. The third experiment occurred a reduction of $3 \mathrm{ppm}$ which means $10.34 \%$ of the initial sensor readings of $29 \mathrm{ppm}$. And the prototype clocked 3 minutes 21 seconds for one round with 1 minute 29 seconds when it reached the smoke. The fourth experiment occurred a reduction of $6 \mathrm{ppm}$, which means $18.75 \%$ of initial sensor readings of 32 ppm. And the prototype clocked 3 minutes 20 seconds for one round with 1 minute 28 seconds when it reached the smoke. The fifth experiment occurred a reduction of $4 \mathrm{ppm}$ which means $13.33 \%$ of initial sensor readings of $30 \mathrm{ppm}$. And the prototype clocked 3 minutes 23 seconds for one round with 1 minute 30 seconds when it 
reached the smoke. The sixth experiment occurred a reduction of $5 \mathrm{ppm}$ which means $15.62 \%$ of initial sensor readings of $32 \mathrm{ppm}$. And the prototype clocked 3 minutes 23 seconds for one round with 1 minute 31 seconds when it reached the smoke.

\section{CONCLUSION}

From this research can be drawn conclusion as proximity sensor PING have mean error percent $6 \%$ on right side, $4 \%$ in center and $4 \%$ on left side. The MQ- 8 AND MQ-9 smoke sensors have an average percent error of $6.5 \%$ on the front and $7.87 \%$ on the back. from the decomposition of the smoke using a tissue material, the robot is able to reduce the carbon (C) level by an average of $14.5 \%$. When reaching the robot smoke takes 2 minutes 10 seconds and the robot takes 4 minutes 30 seconds to reach one round

\section{REFERENCES}

[1]. Dikman, S. 2011. Prototype Pembersih dan Monitoring Asap Rokok pada Ruang Tertutup Menggunakan Fuzzy Logic Controller. Surabaya: ITS.

[2]. Anwari, M. Z. 2011. Informasi Kadar CO dan NOX Berbasis SMS. Yogyakarta:
STMIK AMIKOM. STMIK AMIKOM.

[3]. Gunawan, A., dkk. 2009. Pengukuran kepekatan asap pada lahan gambut. Surabaya: ITS

[4]. Badan Standarisasi Nasional "Angka Parameter dalam Estimasi Potensi Energi Panas Bumi”. SNI 13-6482-2000, accessed 5 Maret 2014, 